\title{
Opinions: alleged herdmen attacks in Nigeria; psychosocial implications for policy makers
}

\begin{abstract}
This paper presents a perspective on the recurrent security challenges in Nigeria. For a while now, the dusk has shifted from a more turbulent North East Nigeria to other parts of the country with a relatively volatile North Central as worst hit areas. What this portrays is an absence of normalcy in these areas and several opinion holders have opined a need for this challenge to be dealt with squarely with government taking the lead. A read through this work highlights different perspectives from different opinion holders.
\end{abstract}

\author{
Volume 9 Issue 5 - 2018
}

\author{
Binan Evans Dami \\ Clinical Psychologist/Writer/Researcher/Mental Health \\ Practitioner, Nigeria
}

Correspondence: Binan Evans Dami, Clinical Psychologist/ Writer/Researcher/Mental Health Practitioner, Nigeria, Email evansbinan@gmail.com

Received: July 30, 2018 | Published: September 12, 2018

\section{Introduction}

For about a decade now, Nigeria has been faced with a couple of security challenges. While these challenges have lingered for so long, a lot of opinions have been held about the causes and likely solutions to these challenges. Many believe that this conflict has a lot to do with the political factors, while others believe that it has a lot to do with religious factors and another group believes it has all to do with geographical and psychosocial factors. However we may want to speak about the causal factors, the solution geared at ending this menace has not come up with reasonable imprints to combat this situation. Just recently, the APC Presidential campaign spokesperson spoke and I quote "what is going on in Nigeria is pure criminality and we have said it over and over again, that at that level we should expect that we should be shouting to douse off the tension in Nigeria. The tension is artificial, it is not real. There is nothing going on in the real sense that suggests that there is anything like ethnic cleansing or religious war in Nigeria. So I can only appeal to elder statesman (Danjuma), to let reason prevail, he should come and assist in dousing the artificial tension. The criminals have killed both Christians and Muslims; the criminals are killing without regards for religion or ethnicity, and the earlier, the louder we make this point, the better for all of them". This statement was a reply to earlier statement by General T.Y Danjuma claiming that the army has colluded with the alleged perpetrators on the incessant killings in Nigeria. We have heard statements and counter statements about these recurrent challenges; and more important of all these comments is the interest seen in every perspective provided. This alleged carnage has been left unabated and many opinion holders have blamed the government while others have seen other factors at play. The aim of this paper would be to x-ray the factors catalyzing this recurrent conflict and provide inherent measures through which this issue could be addressed.

\section{Heart breaking factors transforming humanity into meaninglessness}

1. The kidnap of Olu Falae in his farm at South West Nigeria In September, 2015 by suspected Fulani Herdsmen ( Guardian News, $22^{\text {nd }}$ September, 2015)

2. Alleged Fulani herdsmen set ablaze Olu Falae palm plantation (Punch NG, 22 ${ }^{\text {nd }}$ January, 2018)

3. The killings at Abraka by suspected herdsmen, leaving four persons death (thisdaylive, $13^{\text {th }}$ May, 2017)
4. The persistent killings by armed bandits in Zamfara State

5. More than 500 lives claimed in Plateau in 2018 due to farmers herders clash (Channels, 25 $5^{\text {th }}$ June, 2018)

6. Abraka communitites have raised an alarm over a new pattern of killing by alleged herdsmen (Channels, $1^{\text {st }}$ April, 2017)

7. Bandits kill 36 gold miners in Zamfara ( Punch Newspapers, $9^{\text {th }}$ November, 2016)

8. 8 killed by suspected armed bandits in Zamfara (Daily Trust, $19^{\text {th }}$ March, 2018)

9. Police confirmed 15 persons killed in Zamfara (Premium Times, $20^{\text {th }}$ April, 2018)

10. 13 killed in fresh Zamfara attack by suspected armed bandits and 15 feared death in Adamawa ( Vanguard Nigeria, $3^{\text {rd }}$ may, 2018)

11. The killings in Benue State: "I blame attacks on Federal Government's inability to respond as expected and also the security" (Gov. Samuel Ortom - Punch News, 14 ${ }^{\text {th }}$ January, 2018). (Dami, 2018)

12. The killings in Kogi State by alleged herdsmen in two communities Dekina and Omala leaving about 32 persons death ( Guardian Nigeria News, $16^{\text {th }}$ March, 2018)

13. 10 feared death as herdsmen attacked kaduna village (Premium Times, $13^{\text {th }}$ January, 2018)

14. 23 feared death as herdsmen, armed bandits attack Benue, Taraba and Kaduna states (thisdaylive, $6^{\text {th }}$ April, 2018)

15. Suspected herdsmen attack kills over 25 persons in fresh attack ( Channels, $13^{\text {th }}$ March, 2018)

16. The killings of two reverend fathers in Benue state (Guardian, April 25 $5^{\text {th }}$ 2018)

17. Fresh bloodbath in Benue as two Catholic priests and 17 others killed by gunmen ( Vanguard News, 25 ${ }^{\text {th }}$ April, 2018)

18. IGP directed to relocate to Benue State

19. Fresh bloodbath claims 120 persons in Plateau State, Nigeria. (Core TV news, 25 $5^{\text {th }}$ June, 2018)

20. Withdrawal of soldiers from IDP camp led to the killing of 4 
persons as reported by Taraba Council boss (Monday Vanguard, April, 16 $\left.{ }^{\text {th }} 2018\right)$

\section{Accusations/counter accusations/ support statements/ pronouncements}

1. Danjuma's statement claiming that the army has colluded with criminals to unleash war on Nigerians ( Vanguards Nigeria, $27^{\text {th }}$ March, 2018)

2. T.Y Danjuma's statement on herdsmen attack unfortunate says Nigerian Army ( TVC News, 25 ${ }^{\text {th }}$ march, 2018)

3. T. Y Danjuma's statement an invitation for anarchy says Defense Minister (Daily Post, 25 $5^{\text {th }}$ March 2018)

4. Middle belt youths back Danjuma's claim (Sun News Online, $26^{\text {th }}$ March, 2018)

5. Independent People of Biafra (IPOB) backs Damjuma's claims ( Guardian Nigeria, 25 ${ }^{\text {th }}$ March 2018)

6. Soyinka claims the federal government has abandoned Nigerians. The Herdsmen have invaded Nigeria (Tuesday March $20^{\text {th }}, 2018$ )

7. Christians in a protest urged that the security chiefs be sacked (Vanguard, Monday, April 10 ${ }^{\text {th }}, 2018$ )

8. Herdsmen killing: CAN mobilizes churches for nationwide protest (Punch Nigeria, $28^{\text {th }}$ April, 2018)

9. PDP, APC trade blames over herdsmen killings in Ekiti State (Premium Times, $13^{\text {th }}$ February, 2018)

10. Defense Minister Mansur Dan Ali blames Anti- Grazing Law, not Herdsmen for killings ( thisdaylive, $26^{\text {th }}$ January 2018)

11. Junaid Mohammed accused the government of not making reasonable impact in the areas of security and economy.

12. Trump to Buhari : Protect Nigerians from the spate of killings (Guardian Nigeria, $1^{\text {st }}$ May, 2018)

13. President Buhari associates killing to late Ghadafi's militia (Channels TV, 30 ${ }^{\text {th }}$ April, 2018)

14. President Buhari said herdsmen do not carry AK 47 but sticks (Channels TV, 30 $0^{\text {th }}$ April, 2018)

15. Don't politicize killings by insurgents, Muslim group tells media (May $5^{\text {th }}, 2018$ )

16. Fulani Herdsmen want to take over Benue valley - Rebecca Apedzan (Vanguard Nigeria, $5^{\text {th }}$ May, 2018).

17. We are now ready for killer herdsmen in Delta State decries natives (Metro watch online, $5^{\text {th }}$ March, 2018).

\section{Further opinions from stake holders}

1. Nigeria on time bomb without Restructuring (Emeka Anyaoku, Gen. Lekwot, Nwodo, Adebanjo, Vanguard Nigeria, $3^{\text {rd }}$ may, 2018)

2. Senate will revisit devolution of powers ( May $4^{\text {th }}, 2018$ )

3. Paul Unongo resigned as chairman of Northern Consultative Forum (Leaders Nigeria, $18^{\text {th }}$ January, 2018)

4. Avoid creating anarchy, Sen. Omo Agege warns constituents after
Abraka attack by alleged herdsmen ( Vanguard Nigeria $30^{\text {th }}$ April, 2017)

5. General Gowon calls for peace and unity in Nigeria (Vanguard Nigeria, 24 ${ }^{\text {th }}$ February, 2018)

6. Gen. Abdulsalami sues for peace ( Vanguard News, $5^{\text {th }}$ may,2018)

7. Abdulsalami, Tambuwal, David Mark, Chief of Defense staff, Chief of Army Staff (The Nation, 26 $6^{\text {th }}$ September, 2017).

8. Solution to Africa's security challenges lies within - Obasanjo (Vanguard News, 20 ${ }^{\text {th }}$ April, 2016)

9. Gen. Babangida calls for urgent solution to killings in Nigeria (Channels TV, 14 ${ }^{\text {th }}$ January, 2018)

10. Afenifere vows to protect Yorubas from this alleged herdsmen attack

\section{Nature of the havoc caused by this unrest}

1. 80,450 trapped in 8 IDP camps in Benue state (March 24, 2018)

2. 580 persons killed by alleged herdsmen attack in 2017 while within the first four months of 2018, over 1000 killed by this same alleged group (Amnesty international)

3. About 11,515 displaced and currently at different IDP camps in Jos (Stephanos Foundation, 2018). This comes with other psychosocial factors especially looking the humanitarian intervention circle for Mental Health and Psycho Social Support Services.

\section{Catalyzing factors}

1. A nexus of psychosocial factors are likely to have been catalyzing this conflict across these regions.

2. With the position of Nigeria geographically, and politically, a lot of factors are likely to play out. The position of Nigeria now is likely to be a risk factor as well. The Arab upsprings cutting through Libya, Tunisia, Egypt, etc have resultant effects. (Possibly part of the points the president was trying to explain previously). Also, the uprising in Ivory Coast, Senegal, Mali, Sudan, Gambia, South Sudan, Central African Republic, Mali, DR Congo and with Nigeria at the centre, it is expected that Nigeria might have likely witnessed the proliferation of arms and mercenaries across its porous borders.

3. The rising use of arms across the country may correlate largely with the availability of drugs and substances; therefore the increasing use of substances may likely aggravate the yearning need to spark up violence.

4. Absence of known punishment for perpetrators. The absence of proper punitive measures to deal with those apprehended has made this worst and worst. Behavior that is rewarded is likely to be repeated and behavior that is not rewarded is likely to get extinguished, following the Skinnerian approach. This I may say has been more rewarding than rebuking, hence the act keeps increasing.

5. The climatic change and the adverse effects of desertification should be emphasized. The Sahel and Sudan Savannahs are gradually witnessing the effect of desertification from the Sahara region and since most of the farming system around these 
savannas depended more on livestock, they mostly will have to move inward to get more vegetative lands for grazing of their livestock. This trans-nomadic movement has posed a lot of problems across most of the regions where these clashes exist. More to this is that the tension has already been created.

6. Other factors could relate to the myriad of poverty, unemployment, poor policy formulation and implementation, etc.

\section{Implications}

1. With the food basket of the nation raided so persistently, what is likely to be next would be that people may not feel safe to go to their farmlands and this may limit involvement in farming activities. On a long run, this may eventually lead to shortage of food supply; and while the available may be costly, the frustration from hunger and high prices of goods and services may likely produce some sort of aggression among the people (from frustration/ aggression perspective).

2. In places where this has occurred, people may get scared of other people intruding into their personal spaces and this may likely explain why this mayhem is still happening despite efforts to quench this.

3. The influx of weapons into the hands of wrong persons may give crime a lifeline as other persons may use these weapons to perpetrate other crimes in other parts of the country, especially now that elections are fast approaching.

4. Mental health challenges may be heightened. With the persistent displacements in places that were previously not having any forms of displacements come with feelings of depersonalization and derealization which in turn affects their mental well-being. Eventually, more mental health conditions such as trauma and stressor related disorders, depression and anxiety based disorders are likely to be witnessed on a long run.

\section{Other premeditating factors (After the dusk): No one takes responsibility}

1. No land available for cattle ranching in the West - Afenifere (TVC News, June, 27 $7^{\text {th }}$ 2018)

2. Plateau killings are evidence of abysmal failure in leadership : Atiku Abubakar (TVC News, 27 June, 2018)

3. I am not to be blamed for Plateau killings carried out by herdsmen (PMB, TVC News, 27 $7^{\text {th }}$ June, 2018)

4. Speaker Yakubu Dogara calls for urgent rejig of the security sector, since it has not been able to deal with the spate of killings in the country of late (NTA News, $28^{\text {th }}$ June, 2018)

5. We need quick response to tackle insecurity; Senator Bukola Saraki (25 $5^{\text {th }}$ June, 2018)

6. 70 Billion Naira Ranches not for Fulani alone (FG : Core TV, $25^{\text {th }}$ June, 2018)

7. Military deploys 7 fighter aircraft in Benue and Taraba.

8. IGP deploys special intervention force to troubled areas - Plateau Killings ( Channels, 25 $5^{\text {th }}$ June, 2018)

9. Plateau government imposes curfew in 3 LGAs, ask residents to remain calm (TVC News, 25 $5^{\text {th }}$ June, 2018)
10. President Buhari blames killings on desperate politicians ( Liberty TV, $25^{\text {th }}$ June, 2018)

11. Miyetti Allah condemns invasion, saying attack is retaliatory ( TVC News, $25^{\text {th }}$ June, 2018)

12. Vice President visits Plateau State ( TVC News, $25^{\text {th }}$ June, 2018)

13. Security architecture needs to be decentralized; Ike Ekweremadu ( Channels, 25 ${ }^{\text {th }}$ June, 2018)

14. Call for Re-structuring based on selfish interest; PMB (Tribune online, $25^{\text {th }}$ June, 2018)

15. Buharis government committing same human rights violations of PDP administration; Falana (Premium Times, June 24 ${ }^{\text {th }}, 2018$ ).

16. Bandits taking advantage of your incompetency - Gov. Yari blast Danbazzau (The cable, $23^{\text {rd }}$ June, 2018)

17. The nation in perpetual grief and endless funerals. The inconvenient truth is that Plateau tragedy was not just about a heinous evil against helpless victims, but also about systemic failure of a nation and its government (Sen. Shehu Sani, twitter handle, $25^{\text {th }}$ June, 2018)

18. President Buhari said it is unjust to say he is silent about the spate of killings (TVC News, 27 ${ }^{\text {th }}$ June, 2018)

After the bloodbath (Government - anchored action)

\section{Perspectives: Way forward.....}

1. "Restructure this country" Emeka Anyaoku insists by having 8 federating zones, restructuring as conditions for votes, to ensure one's loyalty to his country and the ethnic group as well. Vanguard Nigeria, $3^{\text {rd }}$ may, 2018) Will this address the problem of insecurity? This is the biggest question at hand.

2. Devolution of the security apparatus to create state policing across all states (and the question I ask is will this help as well, looking at how complex Nigeria is. On a short-run the Governor can respond to issues around but how well will this be sustained? The question in mind will be of sustainability

3. Forming anti grazing bill across states. Will this work? Looking at Taraba, Ekiti and Benue States; while Ekiti has got more relief, Taraba and Benue states are still in anarchy as attacks are being recorded periodically thou in a much reduced rate. Implementing this in states must have to come with other measures to make it more concrete.

4. Creation of more employment opportunities to cater for those whose minds is already on the streets. With a whooping statistic of 87 million Nigerians in poverty (Channels, 25 ${ }^{\text {th }}$ June, 2018), there is a need to work more on this, then after all, we will be able to say that this has been achieved via economic measures. Unemployed youths who mostly take arms will become gainfully employed and crime control could be reduced.

5. Establishment of cattle ranches as advocated for by the government (Will this mediate the situation? It may, it may not, depending deeply on the context of the states. Therefore, with this, what may work in the North West may not work in the South-South, so this is still debatable.

6. In conclusion, no one seems to have an absolute solution to the 
spate of killings currently in Nigeria. Many stake holders have put forth their suggestions and government will have to sit and streamline these ideas and see which works best on the immediate run, mid-term, and then long-run. What is more important here is that government anchors the action plan, enact the suggestions into meaningful laws, and ensure compliance using its apparatus. Often times, we have good laws in place, but the implementation of these laws has being of great concern, leading to poor outcomes. Government must be decisive in ensuring that the right actions are in place so its citizens find renewed hope.

\section{Acknowledgements}

None.

\section{Conflict of interest}

Author declares that there is no conflict of interest. 